\title{
Study on Critical Performance Factors Affecting Kochi Metro Rail Project
}

\author{
Aswathi $\mathbf{P}^{1}$ and Anju Wilson ${ }^{2}$ \\ Research Scholar ${ }^{1} \&$ Professor $^{2}$ \\ Department of Civil Engineering
}

Cochin College of Engineering and Technology

Valanchery, Kerala

India

\begin{abstract}
We are living in a fast-developing society. Every day we are exposing to new technology and development in our locality. The communication system and transportation mechanism connect people around the world so easily with utility of less time, cost and comfort. This kind of development also increases the standard of living of people. Rapid urbanization and intense commercial developments in the recent past have resulted in steep rise in travel demand, putting Kochi's transport infrastructure to stress. Experience has shown that, in cities like Kochi where roads do not have adequate width and which cater to mixed traffic conditions comprising slow- and fast-moving vehicles, road transport can optimally carry 8,000 persons per hour per direction (PHPDT). There is an urgent need to introduce a light Metro system in the city to provide fast, safe, economic, and environment-friendly mode for mass movement of passengers. With growing population and mega development plans coming up for this port city, the travel demand is expected to grow steeply. With inadequate public transport services, passengers will shift to private modes, which is already evident from the high ownership trends in the region. This will not only aggravate the congestion on the city roads but will also increase the pollution level. Here is the study focusing on the factors affecting the performance of the Kochi Metro Construction Project.
\end{abstract}

Key Words: Light Metro system, Public Transport System, Metro rail, Relative Important Index Factor.

\section{INTRODUCTION}

Public Transport System is an efficient user of space and with reduced level of air and noise pollution. As the population of a city grows, share of public transport, whether road or rail-based, should increase. When traffic density increases beyond this level average speed of vehicles comes down, journey time increases, air population goes up and commuters are put to increased level, of inconvenience. In any case, it is not feasible to operate bus transport beyond 10,000 phpdt in mixed transport scenario, obtaining on Kochi city roads. There is an urgent need to introduce a light Metro system in the city to provide fast, safe, economic, and environment-friendly mode for mass movement of passengers. Carrying capacity of Light Metro System is upto 25,000 phpdt, which will be adequate to take care of the traffic problems for Greater Cochin area for the next about 25 years. The Kochi Metro Rail Project was originally envisaged from Aluva to Petta, for a total length of $25.612 \mathrm{~km}$ with 22 stations at an estimated completion cost of Rs. 5181.79 crore. The study mainly focuses on the factors affected to the performance and delay of construction project of Kochi Metro Rail project. 


\subsection{Objectives}

- $\quad$ To identify project success and failure factors

- To study the challenges and impact of Kochi metro rail project

- $\quad$ To find out the factors of causes of delays by Relative Important Index factor method

- $\quad$ To find out the effects of delays

\section{LITERATURE REVIEW}

Yash Kumar mittal and Virendra kumar paul (2018) studied on Identification of critical factors for delay in metro rail projects in India. Metro rail projects are helpful in augmentation of public transport infrastructure. These projects are frequently characterized by time and cost overruns. The aspect of time overrun is undertaken for investigation in this research. Progress of a metro rail project is typically influenced by multiple impediments. These impediments can be an outcome of factors related to owner, contractor, consultant, materials issues, labor issues, technology related aspects and external agents.

Hatkar K B1 and Hedaoo N A1 (2016) focused on the Delay Analysis by Using Relative Importance Index Method In Infrastructure Projects. From total seventy-six factors causing delays, top ten most important factors have been identified which are: Local political interference, Inadequate fund allocation, Improper project planning and scheduling by contractor, Delay in progress payments by client, Escalation of material prices, Weather condition, Delay in payment to suppliers/subcontractors, Insufficient numbers of equipment, Incomplete drawing/detail design and Natural disasters (flood, earthquake, etc.).

Mamata Rajgor, Chauhan Paresh, Patel Dhruv, Panchal chirag and Bhavsar Dhrmesh (2016) studied on Rii \& Impi: Effective Techniques For Finding Delay In Construction Project. The paper addressed the most significant factors and groups to cause delays. Advance arrangement of equipment's should be made or equipment should purchase on rent. The quality and experience of labor supply can have major impact on the projects. Unexperienced labor may lead to inefficient work and may cause accidents during construction. Site management and supervision should be made in a correct manner.

Sanya Sathyan Chakkalakal (2019) proposed about the Influence of Stakeholders on Project Time Overrun. If the developer is not able to understand the problems of external stakeholders, it results in an environment of distrust between the two parties. An effective external stakeholder analysis should identify the possible trade-offs that can be made without adjusting the aspirations of the project. An external stakeholder analysis should be seen as an important component of the decision-making process required in any construction project and as a key input to the external stakeholder management procedure.

\section{STUDY AND DATA COLLECTION}

The data collected to determine the most influential factors on project management of the project was done through a survey by explorative questionnaire to the respondents involved in daily activities of construction works. The questionnaire was designed so that respondents can give the rank to their answers based on their opinions. The analysis of these data was done by a method named relative importance index (RII).

The most commonly used method to identify the critical factors were

- $\quad$ Case study

- $\quad$ Expert opinions

- $\quad$ Questionnaire survey

The factors that are considered for the analysis and the basis of their shortlisting is mentioned as follows

\subsection{Land Acquisition}

Out of 40.409 hectare of land required for the project, an extent of 34.5289 hectare (85\%) has been taken into possession so far. On 23.09.2015 the Government of Kerala had published the Right to Fair Compensation and 
Transparency in Land Acquisition, Rehabilitation and Resettlement (Kerala) Rules, 2015. The Government also published the State Policy for land acquisition. As per the Act and Rules SIA study is mandatory for every land acquisition.

\subsection{Social Impact Assessment, Rehabilitation \& Resettlement Study}

The main objective of the Social Impact Assessment (SIA) study was to conduct a survey of Project Affected People (PAP), formulate an R\&R Policy framework for Kochi Metro and prepare an R\&R Action Plan. A total of 595 households have been surveyed wherein the total $R \& R$ package is estimated to be approximately Rs.25.5 crore for the affected families. Surveys and interactions with the primary stakeholders revealed that their condition for complying with the acquisition was that it has to be done as early as possible without any further delay and the property which becomes non-viable by partial acquisition should be acquired completely by the Government.

\subsection{Governmental clearances}

Government is a major stake holder in public infrastructure projects. Large complex projects require a lot of clearances for start of construction from various ministries, agencies with regard to land, environment, shifting of utilities, pollution, environment etc. The role of government after awarding of work is to see that necessary clearances are provided for timely start of the project.

\subsection{Human resource}

In order to develop its human resources for harnessing their potential to the fullest and for according ample opportunity for realizing individual as well as organizational goals, Company has been making sustained efforts through various training and development activities with focus on upgradation of skills, transfer of skills and knowledge, and training in specialized/advanced skills.

\subsection{Risk Management Policy of the Company}

The Company's Risk Management Policy encompasses maintaining and following appropriate internal control measures which are regularly reviewed by the Audit Committee. As the project execution envisages considerable risk with respect to safety, health and environment the Company has engaged a Consultant for ensuring monitoring of the execution activities and mitigate the risk related to Quality and Safety, wherever possible.

\subsection{Contracts and Tendering}

Contracts and Tendering are two primary phases of planning. These two factors are merged into one head and explained here. Both these factors played an important role, primarily in selection of contractor and defining the roles and conditions that exist between client and the contractor. There was transparency in tendering and contract awarding thereby it is expected that this factor shall not be critical for success but played a vital role in successful completion. The whole work is undertaken by DMRC.

\section{7 $\quad$ Enterprise Resource Planning}

Enterprise resource planning under implementation in the company intends to integrate applications to manage the business and automate many back office functions related to technology, services and human resources. It envisages centralized data storage in order to bring about efficiency in data processing with defined security policies, better company- wide visibility and faster collaboration across all the departments.

\subsection{Corporate Communication Management and presence in Social Media}

The dynamic participation and interaction with the public through the digital media has helped the Company draw out relevant suggestions from the public.The Facebook page of the Company has become one single platform for the public to know everything new about Kochi Metro. Company is constantly monitoring the complaints that are 
received and also have taken necessary actions to resolve them. In addition to Facebook, social media platforms like Instagram, Twitter, YouTube, LinkedIn, Wikipedia etc. are also managed with constant updates

\subsection{Examination of Alternatives}

Due to progressive increase in vehicles and vehicular movement, the roads of Kochi city are not able to bear the load of traffic smoothly especially in main roads. These led to many adverse impacts in different parameters in terms of time, maintenance of road, pollution etc. Hence through expert studies conducted by the consultants deployed by Kochi Metro Rail Ltd, the first phase of the metro corridor will be passing through this road, in the form of Mass Rapid Transport System for the public. This Mass Rapid Transit System (MRTS) will facilitate people to have faster and comfortable movement within the corridor. There is a proposal to integrate all modes of transport to provide seamless mobility.

\subsection{Transit Oriented Development (TOD) Plan}

Transit Oriented Development (TOD) is a mechanism for densification near the Metro corridor with high quality walking environments. The TOD plan envisages a comprehensive framework for urban spaces for enhanced access to the transit network for various income groups in all the strata through increased walking and cycling, enabling the people to live and work closer to the transit, making it the governing principle for development.

\subsection{Solar Plant}

KMRL had taken up the work for the installation of the roof top solar plant of capacity 4MW at stations and the Depot. The solar plant has been installed in all the 11 station roofs and depot buildings, the capacity of which works out to $1386 \mathrm{kWp}$ and generation of electricity has started. On an average, about $3300 \mathrm{kWh}$ per day of energy. In Muttom Depot, vacant land is available where KMRL can install solar panels on the land.

\section{ANALYSIS AND RESULTS}

The factors that were shortlisted from interview and case study are considered for further analysis.

Table 1.1 Selective Factors

\begin{tabular}{|l|l|}
\hline Political Non-Interference & Progress Monitoring \\
\hline Financing & Change Of Method/Methodology \\
\hline Public Sensitization & Speedy Approval \\
\hline Organizational Hierarchy & Work Ethics \\
\hline Efficient Recruitment & Delegation Of Powers \\
\hline Technology Transfer & Contractor Relationship \\
\hline Risk Allocation & Association With Stakeholders \\
\hline
\end{tabular}

\subsection{Relative Importance Index}

The factors to overall delays was examined and the ranking of the attributes as perceived by the respondents was done by use of Relative Importance Index (RII)

$\mathrm{RII}=\sum \mathrm{W} /(\mathrm{A} \times \mathrm{N})$

where $\mathrm{W}=$ Weightage given to each factor by the respondents $\mathrm{A}=$ Highest weight (i.e., 5 in this case) $\mathrm{N}=$ the total number of respondents. 
International Journal of Advances in Scientific Research and Engineering (ijasre), Vol 6 (5), May-2020

Table 1.2 shows the ranking of top factors that causes delay.

Table 1.2 Ranking of Factors

\begin{tabular}{|l|l|l|l|}
\hline SL No & Factor & RII & Rank \\
\hline 1 & $\begin{array}{l}\text { Delay in Land acquisition and site } \\
\text { handover to contractor (A) }\end{array}$ & .68 & 1 \\
\hline 2 & Weather condition (B) & .6 & 2 \\
\hline 3 & $\begin{array}{l}\text { Heavy traffic, over crowd \& other } \\
\text { restrictions on site (C) }\end{array}$ & .6 & 2 \\
\hline 4 & $\begin{array}{l}\text { Unavailability of land for casting } \\
\text { prefabricated structures (D) }\end{array}$ & .56 & 3 \\
\hline 5 & public strikes (E) & .56 & 3 \\
\hline 6 & $\begin{array}{l}\text { Delay in payment (F) } \\
\text { Scope change (G) }\end{array}$ & .48 & 4 \\
\hline 8 & $\begin{array}{l}\text { Change in government regulations } \\
\text { and law (H) }\end{array}$ & .475 & 4 \\
\hline 9 & $\begin{array}{l}\text { Material transport issues during } \\
\text { congestion hours per day (I) }\end{array}$ & .46 & 5 \\
\hline 10 & $\begin{array}{l}\text { Delay in obtaining permits from } \\
\text { local bodies (J) }\end{array}$ & .44 & 7 \\
\hline
\end{tabular}

Table 1.3 The Common Effects of Delays

\begin{tabular}{|l|l|l|l|}
\hline SL No & Factors & RII & Rank \\
\hline 1 & Time overrun & .6 & 1 \\
\hline 2 & Cost overrun & .4 & 4 \\
\hline 3 & Dispute & .44 & 3 \\
\hline 4 & Litigation & .44 & 3 \\
\hline 5 & Arbitration & .52 & 2 \\
\hline
\end{tabular}

\section{CONCLUSIONS}

- $\quad 25$ factors were obtained from case study. These factors must be governed meticulously to reduce delays and for completing projects closer to the planned cost.

- $\quad$ The major delays groups were identified by RII method is: Delay in land acquisition and site handover to contractor.

- $\quad$ Also weather condition is existing as a main cause of delay in Kerala.

- The major effects of delays have been identified which are: Time overrun, Cost overrun and Arbitration.

- $\quad$ The success factors for the performance related are obtained from the case study and expertise talk.

- Speedy approval, Work Ethics, Delegation of powers, Technical expertise meet, Association with stakeholders, Contractor relationship, Efficient Recruitment and progress monitoring are the key factors affecting the performance of Kochi metro project.

\section{RECOMMENDATIONS}

- The selected contractor must have sufficient experience, technical capability, financial capability, and sufficient manpower to execute the project.

- $\quad$ Site should be delivered as soon as possible after project is awarded.

- Initially calculate optimistic duration to execute the project.

- Contractors must plan their work properly and provide the entire schedule to the clients. 
International Journal of Advances in Scientific Research and Engineering (ijasre), Vol 6 (5), May-2020

- $\quad$ Communication and Co-ordination should be proper with the other parties.

\section{FUTURE SCOPE OF WORK}

- $\quad$ Similar research should be performed in various provinces or cities of India.

- In order to providing more reliable data it is required to carry out studies for each specific type of construction projects, including highways, dam construction projects, utilities, etc.

- $\quad$ Surely, detailed surveys required to be performed to find out cash flow problems on delays in construction projects.

- $\quad$ The factors can be validated by other techniques as well to form a framework that can be considered by government of India while planning Metro projects in many upcoming cities.

\section{REFERENCES}

[1] Yash Kumar mittal, Virendra kumar paul, "Identification of critical factors for delay in metro rail projects in India”, IJSRTM, vol 6, No 1, 2018, pp 30-39

[2] Hatkar K B1 and Hedaoo N A1, "Delay Analysis By Using Relative Importance Index Method In Infrastructure Projects", International Journal for civil engineering and concrete structures, ISSN 2455-7714, Vol 1, No.3, Oct 2016

[3] Mamata Rajgor, Chauhan Paresh, Patel Dhruv, Panchal chirag, Bhavsar Dhrmesh, "Rii \& Impi: Effective Techniques For Finding Delay In Construction Project" International Research Journal of Engineering and Technology (IRJET),volume 2 issue: 01, Jan 2016.

[4] Sanya Sathyan Chakkalakal,” Influence of Stakeholders on Project Time Overrun”, International Research Journal of Engineering and Technology (IRJET), volume 06, issue 02, Feb 2019

[5] Jamal M Assbeihat, "Factors affecting delays on private construction projects",volume 7,Issue 2, March April 2016, pp 22-23

[6] Abdul Anwar, Dr. Sohail Ahmad Malik, "A Conceptual Model of delay factors affecting Government funded hydropower projects", Vol 7, no.10,2017

[7] Benjamin Boahene Akomah and Emmanuel Nana Jackson," Factors Affecting performance of contractors on Building Construction Projects: Central Region Gana", Vol 5, Issue 10, Sep 2016 